\title{
APPLICATION PERSPECTIVES OF CORPUS-BASED METHODS WITHIN LINGUO-CULTURAL AND PSYCHOLINGUISTIC ANALYSIS: GERMAN EMOTIONAL CONCEPT SEHNSUCHT
}

\author{
Kostiantyn Mizin \\ ORCID: 0000-0002-5216-6032 \\ kmizin@i.ua \\ Pereiaslav-Khmelnytskyi Hryhorii Skovoroda State Pedagogical University, Ukraine \\ Lesia Ovsiienko \\ ORCID: 0000-0001-6503-7398 \\ lesichkameta@gmail.com \\ Bohdan Khmelnytsky National University of Cherkasy, Ukraine
}

Received February 7, 2020; Revised March 3, 2020; Accepted May 15, 2020

\begin{abstract}
The paper aims at exploring the German emotional concept SEHNSUCHT features on the basis of corpus-based method being part of contrastive linguo-cultural (languageand-culture oriented) analysis of specific linguo-cultural (language-and-culture) concepts. The tested method includes two research procedures: 1) establishing relevant senses of the concept SEHNSUCHT and identifying their basic sense clusters by contrastive translation analysis of concordances built on the basis of the word query Sehnsucht; 2) determining the emotional concepts that can serve as the representatives of the concept SEHNSUCHT in the target linguocultures (languages and cultures). The latter procedure includes processing the co-occurrent profile of the word query Sehnsucht. This profile is an up-to-date definition of the lexeme Sehnsucht. By extrapolating the basic semantic features of this definition on the cognitive features of the concept SEHNSUCHT, the main concept representatives of the latter have been determined. It has been revealed that the basic emotional senses of the concept SEHNSUCHT ('striving', 'desire', 'wish', 'longing', 'mourning for a person one loses', 'passionate attraction' and others) create the following sense clusters: 1) 'intensive inner affection'; 2) 'passionate (sexual) affection'; 3) 'striving for life changes (alternatives)'; 4) 'longing (nostalgia) for life changes (alternatives)'; 5) 'mourning (grief) for another person, often with no hope'. Based on the linguistic corpus statistic data as of the frequency of co-occurrent-like forms, co-occurrents and left- and right-hand collocates of the word query Sehnsucht, the co-occurrent profile of the word was developed. With the help of the relevant definition of the lexeme Sehnsucht studied on the basis of the co-occurrent profile, the basic concept representatives of the concept SEHNSUCHT, i.e. PASSION, DESIRE, SADNESS, were revealed. These concepts can facilitate an adequate transfer of the specific concept SEHNSUCHT to the target languages and cultures, provided no adequate analogue exists. The tested method may be also applied in psycholinguistic studies aimed at mental and verbal categorization of specific emotions.

Keywords: emotion, linguo-cultural concept, contrastive linguo-cultural analysis, corpusbased method, German language, psycholinguistics.
\end{abstract}

(C) Mizin, Kostiantyn; Ovsiienko, Lesia, 2020. This is an Open Access article distributed under the terms and conditions of the Creative Commons Attribution 4.0 International Licence (https://creativecommons.org/licenses/by/4.0/).

East European Journal of Psycholinguistics, 7(1), 111-127. https://doi.org/10.29038/eejpl.2020.7.1.miz 
Мізін Костянтин, Овсіснко Леся. Перспективи застосування корпуснобазованих методик при зіставно-лінгвокультурологічному та психолінгвістичному аналізі: німецький емоційний концепт SEHNSUCHT.

Анотація. Мета статті - виявлення специфіки німецького емоційного концепту SEHNSUCHT на основі корпуснобазованої методики, яка являє собою один із фрагментів зіставно-лінгвокультурологічного аналізу специфічних лінгвокультурних концептів. Методика включає дві дослідницькі процедури: 1) установлення актуальних смислів концепту SEHNSUCHT та визначення його базових смислових кластерів шляхом зіставноперекладацького аналізу конкордансів, побудованих на основі слова-запиту Sehnsucht; 2) визначення тих емоційних концептів, які можуть слугувати репрезентантами концепту SEHNSUCHT у цільових лінгвокультурах. Остання процедура передбачає опрацювання коокурентного профілю слова-запиту Sehnsucht. Цей профіль є актуальною дефініцією лексеми Sehnsucht. Шляхом екстраполяції базових семантичних ознак цієї дефініції на когнітивні ознаки концепту SEHNSUCHT визначаються основні концепти-репрезентанти останнього. Виявлено, що базові емоційні смисли концепту SEHNSUCHT ('прагнення', 'жага', ‘бажання', ‘туга', ‘журба (скорбота) за втраченою людиною', ‘пристрасний потяг' та ін.) утворюють такі смислові кластери: 1) 'інтенсивний внутрішній потяг'; 2) 'пристрасний (сексуальний) потяг’; 3) 'жага до життєвих змін (альтернатив)’; 4) 'туга (ностальгія) за певною життєвою альтернативою, часто утопічна'; 5) 'туга (журба, скорбота) за іншою особою, часто безнадійна'. На основі корпусних статистичних даних щодо частотності коокурентно-подібних форм, коокурентів та лівих i правих колокатів слова-запиту Sehnsucht розроблено коокурентний профіль цього слова. За допомогою актуальної дефініції лексеми Sehnsucht, що опрацьована на основні коокурентного профілю, виявлено базові концепти-репрезентанти концепту SEHNSUCHT - ПРИСТРАСТЬ, ЖАГА та СМУТОК. Ці концепти можуть сприяти адекватному трансферу специфічного концепту SEHNSUCHT до цільових лінгвокультур в умовах відсутності адекватного аналога. Апробована методика може бути застосована також у психолінгвістичних працях, присвячених вивченню ментальної і вербальної категоризації специфічних емоцій.

Ключові слова: емочія, лінгвокультурний концепт, зіставно-лінгвокультурологічний аналіз, корпуснобазована методика, німецька мова, психолінгвістика.

\section{Introduction}

The interdisciplinary nature of the modern science can be distinctly traced in cognitive science embracing the research fields focused on the human mind and mental processes, such as psychology, linguistics, computer- and neuroscience, philosophy and artificial intelligence studies which are divided into a set of derivative disciplines, in particular cognitive psychology and cognitive linguistics. Psycholinguistics is also a part of cognitive science (Stillings et al., 1995, p. 3), as it is of an interdisciplinary nature and focuses on the issues of human cognitive processes.

Each field of cognitive science studies cognitive structures and processes. However, it is psycholinguistics and cognitive linguistics that pay special attention to the direct correlation of these structures and processes with language and speech. Psycholinguistics which appeared a couple of decades earlier than cognitive linguistics has a global purpose of revealing the nature of the mental mechanisms that make it possible for humans to use the language (Garnham, 1985). This purpose determines the fact that psycholinguistics highlights a number of issues connected with mental aspects of language and speech that needs development and involving a wide variety of experimental techniques. Actually, it is a problem that concerns the semantic organization of the mental lexicon of a person and now is being studied by cognitive 
linguistics. Therefore, some researchers consider cognitive linguistics to be a subdiscipline of psycholinguistics (Vater, 2006, p. 177).

However, there is no doubt that within recent thirty years cognitive linguistics has shaped as a completely independent research area considering language to be an integral part of a human's cognition. The cognitive approach focuses on the use of language, i.e. speech as a process based on mental (conceptual, cognitive) structures. Therefore, the study of language may provide information about structures (mechanisms) of a human's world perception and world understanding, in general (cf: Edgar, \& Sedgwick, 2007; Maslova, 2005). To analyze such cognitive structures cognitive linguistics uses mostly methodological tools "borrowed" from psycholinguistic sciences, first and foremost from cognitive psychology, psycholinguistics and gestalt-psychology (image schemes, patterns, frames, scripts, concepts, etc.). Cognitive linguistics widely uses experimental methods developed, among others, by psycholinguists (Talmy, 2007, p. 11).

A close connection of psycholinguistics and cognitive linguistics is proven by the similar issues touched upon by the representatives of these sciences. For instance, psycholinguists have focused on the study of mental and verbal categorization of emotions, since language is considered to be the instrument to explain the nature of emotions (cf: Bahn, Kauschke, Vesker, \& Schwaryer, 2018; Citron, Weekes, \& Ferstl, 2014; Kuperman, Estes, Brysbaert, \& Warriner, 2014). The same issue was studied by adepts of cognitive linguistics at its early stages (Kövecses, 1990; Wierzbicka, 1999), which facilitated the involvement of the new epistemological constructs, in particular emotional concepts (Gawda, 2019), to the study of emotional world of a human being.

The notion of "concept" was readily accepted by researchers of the post-Soviet countries alongside the spread of the ideas of cognitive linguistics, which ensured the shaping of new interdisciplinary areas, i.e. linguo-culture (language-and-culture) studies, the main epistemological unit being linguo-cultural concept (see about "linguo-culture", "linguo-culture concept", "linguo-cultural analyze" and other notions of linguoculturology, e.g.: Kalishchuk \& Lazuka, 2015; Kulpina \& Tatarinov, 2018). It was the moment when active studies of emotional linguo-culture concepts started (Vorkachev, 2007). Lately, a special attention has been paid to specific emotional concepts, in particular in the German linguo-culture (Mizin \& Letiucha, 2019), as the study of such concepts may give new, research-based results concerning the matters of cognitive (conceptual) and verbal categorization of human emotions. Moreover, the analysis of linguo-culturally marked concepts makes it possible to reveal specific senses that demonstrate some features of mentality of a linguo-culture, i.e. open up extraordinary psycho-types of a nation. These studies are regarded as up-to-date, when total globalization is on track.

It should be mentioned that the notion of "specific emotions" covers the notion of "unique emotions" (on this notion see: Power, 2010, p. 32-33) as well, i.e. the emotions which are experienced by only one language ethnos, while others are not aware of them. The boundary between specific and unique emotions is blurry, as it is an extremely difficult assignment both for psycholinguists to detect ethno-uniqueness of emotions (emotional states), since it is impossible to engage in the experiment all linguo-cultures inhabiting our planet, and for linguists, since the contrastive analysis of 
all modern and dead languages of humanity. It must have been a reason for recent attempts to carry out targeted search and determine ethno-unique emotions (feelings, emotional states). It can be illustrated by the project Positive Lexicography of the psychologist T. Lomas, consisting in registering entho-unique - "non-translated" nominations revealing the notions, spread specifically within a certain linguo-culture, e.g.: an Icelandic lexeme sólarfrí means the day off given to employees for them to enjoy a warm sunny day; a Norwegian word tyvsmake denotes the situation when someone, usually while cooking meals, bites a small piece of dish thinking that nobody notices; a Cherokee lexeme yutta-hey means the inner state (which may seem odd to a European) when a person dreams of dying on the wonderful day which this person considers to be the peak of his/her life on earth or fame; a Finnish lexeme sisu has a meaning of a person's being extraordinarily determined to resist any life challenges; in Tagalog the word gigil has a meaning of 'irresistible desire to squash or pinch someone who is very cute and nice'; in Bantu languages the word mbuki-mvuki names the irresistible desire to undress during the dance (Lomas, 2016).

It is remarkable that some of the lexical units mean emotions, familiar in some way to more than one linguo-cultures. Thus, Ukrainians know the emotional state they experience before much expected guests arrive, therefore the word iktsuarpok ('impatience a person experiences checking up many times if the guest has arrived') in the Inuit language may seem not so alien to them. It also concerns the Danish engelengeduld ('Angel's patience') and it needs studying whose "angel's patience” is more ethnically unique, the Danish or Ukrainian one.

Positive Lexicography contains a number of German lexemes denoting emotions, feelings and emotional states the Ukrainian language community is not aware of, in particular the noun Sehnsucht. Its definition in the German-Ukrainian dictionary is as follows: '1) a passionate desire for something; 2) attraction (affection) to someone, something; 3) longing for someone, something' (Ling, 2002), i.e. it renders a wide emotional range, which may cause translation problems, as there is a great difference between a passionate desire and longing. Germans seem to define this lexeme in a simpler way: 'inner, painful longing, strong desire' (DKW, 1997, p. 832). However, we should take into account the polysemantic nature of the noun Verlangen, which bears the semantics of need, and longing, and desire. It is also specified by attributes inner and painful. It complies with the conclusions of psychologists as of the versatile nature of the emotion Sehnsucht, which has a component of utopian nature in its meaning while expressing a passionate desire or striving. Besides, the German Sehnsucht is a much positive emotion than, for instance, English nostalgia (Scheibe, Freund, \& Baltes, 2007, p. 778).

The original and complex emotion Sehnsucht has pushed psychologists to its intensive study (Kotter-Grühn, Scheibe, Blanchard-Fields, \& Baltes, 2009; Mayer, Scheibe, \& Riediger, 2008; Scheibe, Blanchard-Fields, Wiest, \& Freund, 2011). The emotional concept SEHNSUCHT can be regarded as specific and relevant to the modern German-speaking community, due to the high frequency of the lexeme that nominates this concept in discourses of different types. However, this mental construct has not been an object of a special contrastive linguo-cultural analysis yet. It is remarkable that the lexeme Sehnsucht took the third position (after Liebe 'love' and 
Gemütlichkeit 'cosiness') in the nomination of the "most beautiful German word" (Spiegel Online, 2004).

Taking into consideration all mentioned above, the purpose of this paper is to test the corpus-based method as one of the fragments of contrastive linguo-cultural analysis of specific linguo-cultural concepts, in particular the German emotional concept SEHNSUCHT rendering a particular piece of the Germans' emotional world. This method may be applied in a psycholinguistic research of mental and verbal categorization of specific emotions.

\section{Methods}

Psychophysiological processes, in particular experiencing emotions (emotional states), are characteristic of people as a specie, i.e. they are universal. However, it is true for basic emotions only, but not for the derivative ones (complex, combined), which emerge as a result of "tangling” or "overlapping" of the basic emotions (Izard, 2011; Levenson, 2011). These complex emotions, whose quality has not been identified yet (Cowen, \& Keltner, 2017; Du, Tao \& Martinez, 2014), are of social nature and usually differ on the interpersonal level as they arise under socio-cultural factors. The differences on the interpersonal level cause differences in perception of a social emotion on the level of a certain group, and then on the cross-cultural level. It makes the methodological basis for recognizing the fact that in the process of socialization in each linguo-culture social emotion acquires some ethno-cultural specific features, not so much its expression but socio-cultural perception of the emotions. Ethno-cultural specifics of a certain social emotion may be really significant, which makes it to be perceived as unique on the cross-cultural level.

Another methodological foundation for the proposed research is the scientifically grounded idea that the Corpus Linguistics data make the results and conclusions of linguistic research more solid and sound (Adolphs, 2006, p. 7-8).

The corpus-based method of revealing the specifics of the German emotional concept SEHNSUCHT includes the following research procedures:

1) establishing relevant senses of the concept and identifying its basic sense clusters by contrastive translation analysis of modern speech patterns with Sehnsucht as the key word. These patterns are provided by the concordances, automatically built by the query of Sehnsucht. For this purpose, the following representative German linguistic corpora are used: Digitales Wörterbuch der deutschen Sprache (DWDS) and Leipzig Corpora Collection (LCC);

2) determining the emotional concepts that most closely correlate with the concept SEHNSUCHT, i.e. that are its main representatives. Revealing such concepts may facilitate an adequate transfer of this specific concept to the target linguo-cultures, provided there are no adequate analogues. This procedure includes working on the cooccurrent profile of the query Sehnsucht with the help of digital functions and statistic data represented in the corpus Leipzig Corpora Collection (LCC). The co-occurrent profile includes condensed calculations of psychologically real syntagmatic and paradigmatic "setting" of a certain lexeme based on the preference-rational approach (Belica, 2011, p. 172). By means of the condensed co-occurrent profile, it is possible to identify the language profile of the lexeme Sehnsucht, its relevant definition, as the 
basic semantic features of this definition objectify the main cognitive features of the concept SEHNSUCHT. These features point to the concepts that most closely correlate with the concept under consideration, representing it in the target linguo-cultures.

It is remarkable that defining a specific emotion is a necessary stage for both contrastive linguo-cultural and psycholinguistic analysis of a specific emotion, feelings or emotional states.

\section{Results and Discussion}

Contrastive translation analysis of the fragments of concordances containing the noun Sehnsucht as a search lemma, made it possible to reveal the fact that in this word, an "additional" sense component can be traced in all cases, and this sense cannot be compensated in translation. This very fact proves the specific character of the German lexeme Sehnsucht and, correspondingly, of the emotion it is used to denote.

The language objectification of the concept SEHNSUCHT gives grounds to claim that the basic sense cluster for this concept is 'a powerful inner affection (attraction)'. The cluster embraces a wide emotional range: from a simple wish to longing (yearning). Emotions and feelings are so tangled in this concept that it is highly difficult to single out just one of them. If one of the emotions or a certain feeling is singled out during the objectification, they are still not "pure”, i.e. its 'outline' stays blurry as a result of "overlapping" with other emotions and feelings.

The main emotional senses of the concept SEHSUCHT are as follows:

1) 'affection': Für die Führer der Regierungen sei es eine heilige Pflicht, die Sehnsucht nach Frieden zu erfüllen // It is a sacred duty for the government leaders to fulfill their affection (desire) for peace;

2) 'desire': [...] Texte erzählten von Einsamkeit und Verlorenheit, handelten von den Augenblicken des kurzen Glücks, von der Sehnsucht nach Liebe [...] // Texts told about loneliness and seclusion, about moments of short happiness, about the desire for love;

3) 'wish': Ein Mädchen vom Lande zieht in die Stadt, um dort ihre diffusen Sehnsüchte und namenlosen Träume zu verwirklichen // A country girl moves to the city to realize her diffuse wishes and nameless dreams;

4) 'passionate hope': Die Sehnsucht ist wieder da, dass da einer kommt, der mit fester Stimme sagt: Alles wird gut // The (passionate) hope is back again that someone will come, who will say in a firm voice: Everything will be fine;

5) 'inner need': Es war Digitale Entgiftung, die Sehnsucht, ganz weit weg zu sein, geografisch, aber vor allem von jedem WLAN oder Handy-Funkmast // It was a digital detoxification, the inner need to be far away, geographically, but first of all from any WLAN or cell phone mast;

6) 'need': Offenbar gibt es in unserem Land eine große Sehnsucht nach Leuten, die [...] // Apparently there is a great need for people in our country, who [...];

7) 'longing': Borowski überkommt die Sehnsucht nach Schweden [...] // Borovski gets filled with the longing for Sweden [...];

8) 'nostalgia': Und die Sehnsucht nach einem vergangenen Amerika, das vielen Anhängern Trumps als das bessere erscheint // And the nostalgia for a past America that seems as something better to many supporters of Trump (it is remarkable that the 
emotions Nostalgie and Sehnsucht are differentiated by the German language speakers, e.g.: Was auf spätere Betrachter wie Nostalgie und Sehnsucht nach dem Ritual wirkt, ist in Wirklichkeit das Gegenteil [...] // The thing that affects the later viewers is actually something different to nostalgia and the longing for the ritual [...]);

9) 'grieving (mourning) for a lost person': Voller Sehnsucht nach der verlorenen Geliebten irrt er durch die Schweizer Bergwelt und sucht Erlösung // Mourning for his beloved, he wanders through the Swiss mountains and seeks redemption.

Considering the analysis of the factual material, one can state that there is a close correlation between the concepts SEHNSUCHT and LIEBE (love; romance), e.g.: Liebe ist eine Hoffnung, eine Sehnsucht, kein Faktum // Love is hope, desire, not a fact. However, the concept SEHNSUCHT contains the senses of love as a feeling between two different genders. These senses are part of one of the integral sense clusters of the concept, namely 'passionate attraction', meaning love and physical (sexual attraction), and irresistible desire to be close to the person you adore, e.g. [...] aber als ich weiterlese, wird mir deutlich, dass mit der Sehnsucht nach Neuem durchaus auch die Sehnsucht nach dem anderen Geschlecht gemeint ist // [...] as I go on reading, it becomes clear to me that the desire for something new also means the desire for some other gender; Gelbe Rosen stehen für die Sehnsucht nach heißen Küssen // Yellow roses mean the desire for hot kisses. In the "naive" perception of the representatives of the German language community the emotion Sehnsucht is an amalgam of these feelings and natural attractions (needs), e.g.: Die Sehnsucht nach Liebe, Sex und Zärtlichkeit ist groß, auf die Schnelle aber kein geeigneter Partner zu Hand // The desire for love, sex and tenderness is great, but for a quick romance there is not an available partner.

Taking into account all mentioned above, one can consider translating the American film by Elia Kazan A Streetcar Named Desire into German as follows: Endstation Sehnsucht, as the English noun desire renders a range of emotions, but first and foremost the passionate wish, including love and sexual attraction (NWDTEL, 1993, p. 259). On the other hand, it seems inadequate to translate the film into Ukrainian as Tramvai Bazhannia and into Russian as Tramvai Zhelaniye since desire is much more than a neutral bazhannia (Rus. zhelaniye) 'wish'. Therefore, it would be better to use lexemes prystrast' 'passion' or kokhannia 'love'.

The emotion Sehnsucht is so specific that its translation often requires the use of attributive specifications or contextual substitution, e.g.:

1) Ich schwelge nicht in Erinnerungen und habe auch keine Sehnsüchte // I do not dive into dreams and I have no passionate aspirations;

2) Dass jemand seinen Sehnsüchten so viel Raum gab [...] // That someone gives their inner aspirations such a vast space [...];

3) Sie haben eine Sehnsucht nach Neugier geweckt // They woke an intensive attraction to inquisitiveness;

4) Wenn Menschen ihren Job nicht mögen oder ihre Ehefrau [...] dann kommt eine Sehnsucht nach einem anderen Leben zum Ausdruck [...] // When people do not love their work or their wives [...], a burning need for other life realizations arise [...]; 
5) In der Türkei werden Menschen gefoltert, Leben zerstört, Sehnsüchte okkupiert // In Turkey people are tortured, lives are ruined, wishes, hopes and feelings are alienated;

6) So ist das eben mit den Sehnsüchten - ein wenig Verklärung gehört dazu // This is how it works with inner aspirations, wishes and hopes, some inconsiderable transformations are needed here;

7) Jetzt hab ich den ganzen Tag Sehnsucht nach ihr und muss sie mir aus dem Kopf schlagen // Now I am longing for her all day long and have to stop thinking about her.

Identifying the senses of ethno-cultural concepts can appear as the most difficult case for an "alien" linguo-culture, when one specific concept is denoted by another one. For instance, one of the edges of the concept SEHNSUCHT, the concept FERNWEH, bears unique senses (Mizin, Letiucha, \& Petrov, 2019, p. 64-67). Therefore, a representative of the Ukrainian-language community finds it difficult to understand the meaning of the following sentence: Die Sehnsucht hat viele Facetten, Fernweh gehört auch dazu // Desire has many facets, wanderlust belongs here, too.

The concept SEHNSUCHT contains profound senses, e.g.: Blaue Blumen stehen für sehr tiefe Gefühle und die Sehnsucht nach Unendlichkeit // Blue flowers stand for very deep feelings and desire stands for infinity. Deep emotions and feelings are secret, intimate, i.e. they always contain a small part of a certain individual, e.g.: In dieser Komposition mischen sich Sehnsucht, Demut und Vertrauen, und wurden verwoben von der Sopranistin // In this composition desire, humility and trust are mixed and they were interwoven by a soprano. Depending on the emotional situation that tunes an individual to experience a certain emotional state, the concept SEHNSUCHT activates positive or negative senses in the consciousness of an individual.

A profound and mysterious nature of the emotion Sehnsucht can even transform into a maniac state when one of the passions turns into a mania causing the manicsuicidal depression (Bloch, 1967). This psychopathological state is denoted in German as Todessehnsucht.

Thus, the contrastive translation analysis demonstrated that the concept SEHNSUCHT contains senses that form a wide range of emotions characterized by different intensity: basic and complex, positive and negative, representing culturally relevant fragment of the Germans' emotional state. This concept is represented by emotions that can be conventionally embraced by the following sense clusters: 1) 'intensive inner affection' (attraction); 2) 'passionate (sexual) attraction'; 3) 'desire for life changes (alternatives)'; 4) 'longing (nostalgia) for a certain life alternative, often utopian; 5) 'longing (yearning) for another person, often hopeless'.

The fixation of these clusters as reference information about the concept SEHNSUCHT may form rather an incomplete idea in the target language community about this German emotion. Therefore, taking into account that there are no similar concepts in the target linguo-culture, the closest analogies of the concept should be found, i.e. identify the range of concepts that most closely correlate with the concept SEHNSUCHT. For this purpose, it would be methodologically correct to carry out a psycholinguistic (association) experiment. However, it requires the involvement of material and human resources to engage German language speakers as respondents. In 
Ukraine, for example, it is actually impossible to carry out such an experiment, as it requires the involvement of at least 100 respondents. Therefore, it is necessary to apply alternative procedures that along with associational ones can be considered as methodologically reliable.

Today, corpus-based methods are considered to be an alternative to the association methods. The former exploit statistic data that can considerably improve the reliability of the results and conclusions of linguistic research. By means of such data there were identified the most frequent for the word query Sehnsucht (1) co-occurrentlike forms; (2) co-occurrents and (3) left- and right-hand collocates.

1. The most frequent co-occurrent-like forms: Bedürfnis (0.20), Neugier (0.17), Wut (0.16), Dankbarkeit (0.16), Melancholie (0.15), Liebe (0.14), Neugierde (0.14), Leidenschaft (0.14), sehnen (0.14), Verzweiflung (0.13), Trauer (0.13), Zuneigung (0.13), Hoffnung (0.13), Lust (0.12), Gier (0.12), Einsamkeit (0.12), Gefühle (0.12), Angst (0.12), Verbundenheit (0.12), Vorfreude (0.12), Freude (0.12), Begeisterung (0.11), Sorge (0.11), Emotionen (0.11), Zufriedenheit (0.11), Lebensfreude (0.11), Zuversicht (0.10), Misstrauen (0.10), Träume (0.10), Fantasie (0.10), Überzeugung (0.10), Enttäuschung (0.10), Bedürfnisse (0.10), Ängste (0.10), Motivation (0.09), Hoffnungen (0.09), Wunsch (0.09), Skepsis (0.09), Erwartungen (0.09), Freiheit (0.08), Heimat (0.08).

2. The most frequent co-occurrents: nach $(17,512)$, Liebe $(1,514)$, Endstation Sehnsucht (1,218), Heimat (1,003), die (873), und (777), Freiheit (701), Geborgenheit (666), groß (639), Endstation (625), Leben (616), Frieden (539), stillen (507), tiefe (484), einer (453), dem (449), Menschen (442), Welt (393), weckt (346), Ferne (342), nach mehr (340), voller (337), Ausdruck (325), Einsamkeit (292), ist (290), Gott (287), Natur (285), wächst (272), größer (265), Wunsch (265), Die (245), gestillt (240), alten (236), Glück (226), unerfüllte (220), diese (218), Wärme (218), erfüllt (218), stillt (217), eine (211), Fernweh (211), Entschleunigung (210), Heimweh (210), Sonne (208), einem (207), Melancholie (206), Meer (202), große (201), Hoffnung (200), Erfüllung (193), danach (190), Ruhe (188), Zeiten (187), Jennifer - Sehnsucht nach was Besseres (176), Schmerz (176), unstillbare (166).

3. The most frequent left-hand collocates:

- nominative: Endstation (1,019), Café (84).

- adjectival and adverbial: tiefe (738), große (681), voller (463), unerfüllte (294), unstillbare (238), nostalgische (154), diffuse (131), uralte (123), menschliche (114), gewisse (112), wachsende (103), heimliche (94), ungestillte (77), alte (52), spirituelle (50), unbändige (49), starke (49), unendliche (48), ewige (48), irrationale (47), verbreitete (44), nostalgischen (43), Selige (40), geheime (38), verwurzelte (36), stille (33), unbestimmten (32).

- verbal: weckt (56).

4. The most frequent right-hand collocates:

- nominative: nach dem Leben (149), Torre (77), Flügel (15), Gottes (12).

- adjectival and adverbial: groß (6.2).

- verbal: gestillt (53), kennt (46), getrieben (38), stillen (37), wecken (35), gespürt (34), weckt (28), packt (28), erwartet (27), treibt (25), erfüllten (24), geweckt (19), 
singen (18), steckt (17), darstellt (15), bleibt (13), geprägt (10), erzählen (9.5), erfüllt (8.9), wächst (7.7), warten (5.5), blieb (4.2), zieht (4.2), erzählt (4.0).

The previously mentioned frequency indices of syntagmatic and paradigmatic combinability of the word query Sehnsucht corroborate to a great extent the results of the foregoing contrastive translation analysis of the fragments of concordances containing the word in question.

Thus, by the frequency criterion, the first ten of co-occurrent-like forms of the word query under consideration include the following nominative tokens: Bedürfnis 'need', Neugier 'curiosity', Wut 'fury; rage; wrath', Dankbarkeit 'gratitude', Melancholie 'melancholy; sadness, yearning', Liebe 'love; romance', Neugierde 'interest (often to the opposite sex)', Leidenschaft 'passion', Verzweiflung 'despair', Trauer 'grief; mourning'. The only verbal token here is sehnen. This can be accounted for by the fact that the verb sich sehnen 'being sad; strive' is one of the components of the composite Sehnsucht. The common characteristic of these tokens is the fact that they denote emotions represented in the main sense clusters of the concept SEHNSUCHT. This fact is in full compliance with the fact that co-occurrent-like forms are the words that have similar distribution to that of the word query, so they have similar meaning.

On the other hand, the most frequent nominative co-occurrents, i.e. words which demonstrate the same combinability as the word query, include not only nouns denoting emotions, but also those naming abstract existential notions, e.g.: Heimat 'Motherland', Freiheit 'freedom', Geborgenheit 'security; feeling secure, safe', Leben 'life', Frieden 'peace', Menschen 'people', Welt 'world', Ferne 'distance', Gott 'God', Natur 'nature'. However, the most frequent is still the emotion of Liebe 'love; romance'. The most frequent adjectival tokens are though the word-forms of groß 'great', tiefe 'deep', voller 'full', while verbs include stillen 'to still, weckt 'wakes', wächst 'grows'.

The aforementioned statistic data correlate with the frequency of left- and righthand collocates of the word query Sehnsucht. Thus, the most frequent attributes of the noun Sehnsucht, its left-hand collocates, are tiefe 'deep', große 'great', voller 'full', unerfüllte 'unfulfilled', unstillbare 'unquenchable', nostalgische 'nostalgic', diffuse 'blurry', uralte 'ancient', menschliche 'human', gewisse 'certain', wachsende 'increasing', heimliche 'secret', etc.

The right-hand collocates are mostly verb tokens. The most frequent of them is the lemma stillen 'to still; to quench' and its word-forms gestillt, the verb wecken 'to wake up, to rouse' and its word-forms weckt and geweckt, the tokens getrieben and triebt of the verb treiben 'to cause, to drive', the word-form gespürt of the verb spüren 'to feel', the token packt of the verb packen 'to embrace', the lemma warten 'to wait' and the token erwartet of the verb erwarten 'to wait', the word-form erfüllten and erfüllt of the verb erfüllen 'to fill in; fulfil', etc.

To illustrate the co-occurrent profile of the word query Sehnsucht, it would be reasonable to provide the most frequent and representative results of the digital processing of the word (see: Table 1; Table 2 in Appendix).

The illustration of the co-occurrent profile of the word query Sehnsucht made it possible to reveal that the set of the most frequent tokens represent both syntagmatic 
and pragmatic distribution of the latter. These tokens form the peak 'nodes' of the profile (see Fig. 1).

Figure 1

Peak "nodes" of the co-occurrent profile of the word query Sehnsucht

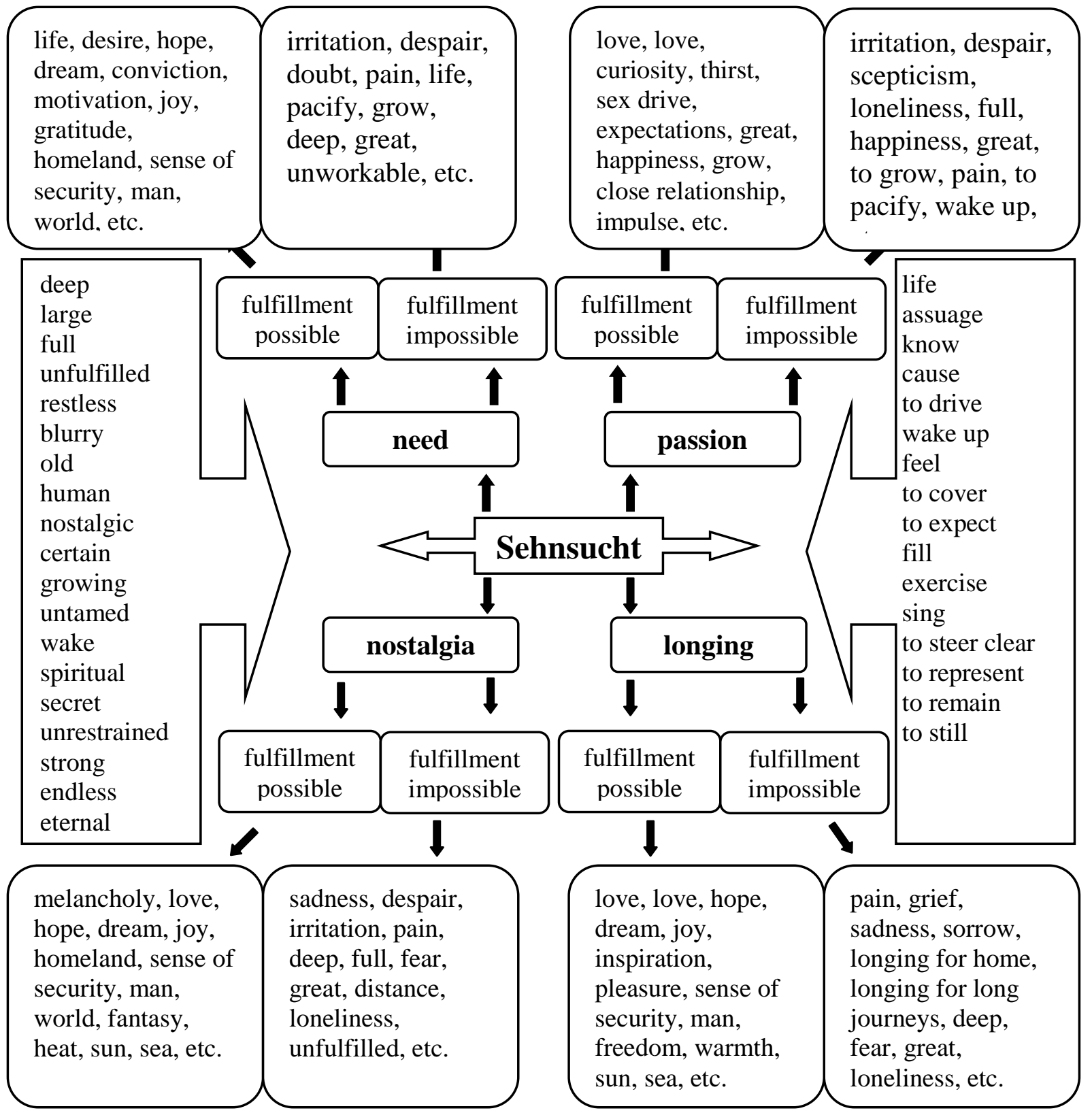

To create a concentrated co-occurrent profile of the word query in question, it should be noted that the digital data unambiguously prove the emotion Sehnsucht to be an intensive one. Therefore, a neutral need would be reasonable to replace by affection or desire, and nostalgia by sadness or longing. Thus, we can distinguish between three content fragments of the lemma Sehnsucht: '1) deep passionate affection to another person, including the sexual attraction (usually hopeless); 2) irresistible striving, a strong desire for life changes and alternatives (usually unfulfillable, utopian); 3) deep sadness, nostalgic longing for someone or somebody 
impossible to reach or lost, including the grieving and mourning for a lost person'. These fragments comprise the co-occurrent profile of the word query Sehnsucht in the concentrated form.

The co-occurrent profile is actually a relevant definition of the emotion Sehnsucht. Defining this emotion is a highly important stage of research, as there is no similar specific emotion in the target language community, which results in the fact that there are no language means to denote this emotion, while dictionary definitions are mostly inaccurate and incomplete. Moreover, the definition analysis is one of the initial stages of both contrastive linguo-cultural and psycholinguistic study of specific emotions. Thus, the adherents of Contrastive Linguoculture start studying linguo-culture concepts, in particular emotional ones, with exploring their names (etymological, definitional and contextual analysis). In fact, the same procedure is carried out by psychologists when they study the features of mental and verbal categorization of specific emotions.

Another important result of the research is that the actual definition of the lexeme Sehnsucht denoting the relevant ethno-specific concept can facilitate a more adequate perception of the concept by representatives of the target language communities, which is especially important for successful communication on the cross-cultural level. As soon as the analysis of the language objectification of the concept SEHNSUCHT revealed that it is represented by numerous emotional and non-emotional concepts, it is necessary to determine which concepts correlate with them most closely. These concepts can create a close to adequate perception of the German specific concept SEHNSUCHT when introduced to the target linguocultures. Such concepts are distinctly traced in three fragments of the concentrated co-occurrent profile, they are as follows: PASSION, DESIRE and SADNESS.

It means that the concept SEHNSUCHT represents the senses of a social emotion where the positive (passion and desire) transforms immediately into the negative (sadness), since the prospects of individual's realization are annulled by the utopian character of these prospects. In other words, "sweet" fantasies, hopes and dreams are neutralized by the "bitter" impossibility for them to come true. It is the reason why psychologists define this emotion as "bitter-sweet" (Scheibe, Freund, \& Baltes, 2007, p. 779). Although this emotion Sehnsucht is considered to be specific to the German linguo-culture, it is known to other language communities, though in an incomplete and fragmental form (Scheibe, Blanchard-Fields, Wiest, \& Freund, 2011, p. 605). It is obvious that each person may experience such emotional state when harsh reality is replaced by "sweet" dreams for a short period, resulting in happy hope and sad hopelessness simultaneously.

\section{Conclusions}

The paper attempts to test the corpus-based method which is one of the fragments of contrastive linguo-culture analysis of the German specific concept SEHNSUCHT. Two research procedures helped identify that the concept SEHNSUCHT contains a wide range of emotions of different intensity representing the linguo-culturally relevant fragment of the Germans' emotional world. 
It was revealed that the main emotional senses of the concept SEHSUCHT are as follows: 1) 'affection'; 2) 'desire'; 3) 'wish'; 4) 'passionate hope'; 5) 'inner need'; 6) 'need'; 7) 'nostalgia'; 9) 'grief (mourning) for a lost person; 10) 'passionate attraction'; 11) 'sexual attraction to the other gender'. These senses create the following sense clusters: 1) 'intensive inner affection'; 2) 'passionate (sexual) affection'; 3) 'yearning for life changes (alternatives)'; 4) 'longing (nostalgia) for a certain life alternative, often utopian one'; 5) 'longing (grief, mourning) for another person, often hopeless'.

On the basis of the corpus statistic data about the frequency of co-occurrentlike forms, co-occurrents and left- and right-hand collocates of the word query Sehnsucht, the co-occurrent profile of the word was developed: '1) a deep passionate affection to another person, including sexual one (usually hopeless); 2) irresistible striving, a strong desire for life changes and alternatives (usually unfulfilled, utopian); 3) deep sadness, grief for a lost person'. The latter is simultaneously a relevant definition of the lexeme Sehnsucht. The basic semantic properties of the definition objectify the main cognitive features of the concept SEHNSUCHT that point out the concepts, which correlate most closely with it, they are PASSION, DESIRE and SADNESS. The amalgam of these emotional concepts creates an original fragment of the Germans' emotional world represented by the concept SEHNSUCHT.

The tested research method can be applied not only in contrastive linguocultural, but also in psycholinguistic studies aimed at the analysis of mental and verbal categorization of specific emotions.

\section{References}

Adolphs, S. (2006). Introducing Electronic Text Analysis: A practical guide for language and literary studies. London: Routledge. https://doi.org/10.4324/9780203087701

Bahn, D., Kauschke, Chr., Vesker, M., \& Schwaryer, G. (2018). Perception of Valence and Arousal in German Emotion Terms: A Comparison between 9-year-old Children and Adults. Applied Psycholinguistics, 39(3), 463-481. https://doi.org/10.1017/S0142716417000443

Belica, C. (2011). Semantische Nähe als Ähnlichkeit von Kookkurrenzprofilen. In A. Abel \& R. Zanin (Hrsg.), Korpora in Lehre und Forschung (pp. 155-178). Bozen-Bolzaro: Freie Universität.

Bloch, R. (1967). Über die Bedeutung der Todessehnsucht für psychogene Störungen des Ernährungstriebes. Zeitschrift für Psychosomatische Medizin und Psychoanalyse, 13(1), 63-69.

Citron, F., Weekes, B. S., \& Ferstl, E. C. (2014). How are Affective Word Ratings Related to Lexicosemantic Properties? Evidence from the Sussex Affective Word List. Applied Psycholinguistics, 35, 313-331. https://doi.org/10.1017/S0142716412000409

Cowen, A. S., \& Keltner, D. (2017). Self-report Captures 27 Distinct Categories of Emotion Bridged by Continuous Gradients. Proceedings of the National Academy of Sciences, 114(38), 7900-7909. https://doi.org/10.1073/pnas.1702247114

DKW. (1997). Der kleine Wahrig. Wörterbuch der deutschen Sprache. Gütersloh: Berstelsmann Lexikon.

Du, S., Tao, Y., \& Martinez, A. M. (2014). Compound Facial Expressions of Emotion. Proceedings of the National Academy of Sciences, 111(15), 1454-1462. https://doi.org/10.1073/pnas.1322355111.

DWDS Digitales Wörterbuch der deutschen Sprache. Retrieved from http://www.dwds.de/ressourcen/korpora/ 
Edgar, A., \& Sedgwick, P., (eds). (2007). Cultural Theory: The Key Concepts. London: Routledge.

Garnham, A. (1985). Psycholinguistics: Central Topics. London \& New York: Methuen.

Gawda, B. (2019). The Structure of the Concepts Related to Love Spectrum: Emotional Verbal Fluency Technique Application, Initial Psychometrics, and Its Validation. Journal of Psycholinguistic Research, 48, 1339-1361. https://doi.org./10.1007/s10936-019-09661-y

Izard, C. E. (2011). Forms and Functions of Emotions: Matters of Emotion-Cognition Interactions. Emotion Review, 3, 371-378. https://doi.org/10.1177/1754073911410737

Каліщук Д., Лазука О. Особливості вербалізації концепту freedom в американському політичному дискурсі доби «холодної війни». East European Journal of Psycholinguistics, 2015. T. 2, № 1, C. 52-58. Retrieved from http://eepl.at.ua/_ld/0/66_eejpl_journal_2.pdf

Kotter-Grühn, D., Scheibe, S., Blanchard-Fields, F. \& Baltes, P. B. (2009). Developmental Emergence and Functionality of "Sehnsucht" (Life Longings): The Sample Case of Involuntary Childlessness in Middle-aged Women. Psychology and Aging, 24(3), 634-644. https://doi.org/10.1037/a0016359

Kövecses, Z. 1990. Emotion Concepts. New York: Springer.

Kulpina, V., \& Tatarinov, V. (2018). Dictionary of Linguoculturology Terms as a Solution to the Current Research Problem. Open Journal for Studies in Linguistics, 1(1), 15-20. https://doi.org/10.32591/coas.ojsl.0101.02015k

Kuperman, V., Estes, Z., Brysbaert, M., \& Warriner, A. B. (2014). Emotion and Language: Valence and Arousal Affect Word Recognition. Journal of Experimental Psychology: General, 143, 1065-1081. https://doi.org/10.1037/a0035669

LCC Leipzig Corpora Collection: Deutsches Nachrichten-Korpus basierend auf Texten gecrawlt 2018. Retrieved from http://corpora.uni-leipzig.de/de/res?word=Sehnsucht\&corpusId= deu_newscrawl-public_2018

Levenson, R. W. (2011). Basic Emotion Questions. Emotion Review, 3, 379-386. https://doi.org/10.1177/1754073911410743

Ling. (2002). Sistema Elektronnyih Slovarey [System of Electronic Dictionaries]. ABBYY Lingvo 8.0. Software House.

Lomas, T. (2016). Towards a Positive Cross-cultural Lexicography: Enriching Our Emotional Landscape through 216 "Untranslatable” Words Pertaining to Well-being. The Journal of Positive Psychology, 11(5), 546-558. https://doi.org/10.1080/17439760.2015.1127993

Маслова, В. А. Когнитивная лингвистика. Минск: ТетраСистемс, 2005.

Mayer, S., Scheibe, S. \& Riediger, M. (2008). (Un)Reachable? An Empirical Differentiation of Goals and Life Longings. European Psychologist, 13(2), 126-140. https://doi.org/10.1027/1016-9040.13.2.126.

Mizin, K., Letiucha, L., \& Petrov, O. (2019). Deutsche linguokulturelle Konzepte im Lichte der germanisch-ostslawischen Kontraste: Methode zur Feststellung von spezifischen bzw. einzigartigen Bedeutungen. Germanoslavica, 30(1), 49-70.

Mizin, K., \& Letiucha, L. (2019). The linguo-cultural concept TORSCHLUSSPANIK as the representative of ethno-specific psycho-emotional state of Germans. PsycholinguisticsPsiholingvistika, 25(2), 234-249. https://doi.org/10.31470/2309-1797-2019-25-2

NWDTEL. (1993). New Webster's Dictionary and Thesaurus of the English Language. Danbury CT: Lexicon Publications.

Power, M. (2010). Emotion-Focused Cognitive Therapy. Chichester: Wiley.

Scheibe, S., Freund, A. M., \& Baltes, P. B. (2007). Toward a developmental psychology of Sehnsucht (life longings): The optimal (utopian) life. Developmental Psychology, 43(3), 778-795. https://doi.org/10.1037/0012-1649.43.3.778

Scheibe, S., Blanchard-Fields, F., Wiest, M. \& Freund, A. M. (2011). Is longing only for Germans? A cross-cultural comparison of Sehnsucht in Germany and the United States. Developmental Psychology, 47(3), 603-618. https://doi.org/10.1037/a0021807 
Spiegel Online. (2004, October 25). "Habseligkeiten” ist schönstes deutsches Wort ["Belongings" is the most beautiful German word]. Retrieved from http://www.spiegel.de/kultur/gesellschaft/0,1518,324670,00.html

Stillings, N. A., Chase, Chr. H., Weisler, S. E., Feinstein, M. H., Garfield, J. L., Rissland, E. L., \& Weisler, S. W. (1995). Cognitive Science: An Introduction. Cambridge, MA: MIT Press. https://doi.org/10.1002/acp.2350030113

Talmy, L. (2007). Foreword. In M. Gonzalez-Marquez, I. Mittelberg, S. Coulson \& M. J. Spivey

(Eds.), Methods in Cognitive Linguistics (pp. 11-21). Amsterdam: John Benjamins.

Vater, H. (2006). On the Mental Lexicon. Studi Linguistici e Filologici Online, 4(1), 175-204.

Воркачев С. Г. Любов как лингвокультурный концепт. М.: Гнозис, 2007.

Wierzbicka, A. (1999). Emotions Across Languages and Cultures: Diversity and Universals. Cambridge: Cambridge University Press. https://doi.org/10.1017/CBO9780511521256

\section{References (translated and transliterated)}

Adolphs, S. (2006). Introducing Electronic Text Analysis: A practical guide for language and literary studies. London: Routledge. https://doi.org/10.4324/9780203087701

Bahn, D., Kauschke, Chr., Vesker, M., \& Schwaryer, G. (2018). Perception of valence and arousal in German emotion terms: A comparison between 9-year-old children and adults. Applied Psycholinguistics, 39(3), 463-481. https://doi.org/10.1017/S0142716417000443

Belica, C. (2011). Semantische Nähe als Ähnlichkeit von Kookkurrenzprofilen. In A. Abel \& R. Zanin (Hrsg.), Korpora in Lehre und Forschung (pp. 155-178). Bozen-Bolzaro: Freie Universität.

Bloch, R. (1967). Über die Bedeutung der Todessehnsucht für psychogene Störungen des Ernährungstriebes. Zeitschrift für Psychosomatische Medizin und Psychoanalyse, 13(1), 63-69.

Citron, F., Weekes, B. S., \& Ferstl, E. C. (2014). How are affective word ratings related to lexicosemantic properties? Evidence from the Sussex Affective Word List. Applied Psycholinguistics, 35, 313-331. https://doi.org/10.1017/S0142716412000409

Cowen, A. S., \& Keltner, D. (2017). Self-report captures 27 distinct categories of emotion bridged by continuous gradients. Proceedings of the National Academy of Sciences, 114(38), 79007909. https://doi.org/10.1073/pnas.1702247114

DKW. (1997). Der kleine Wahrig. Wörterbuch der deutschen Sprache. Gütersloh: Berstelsmann Lexikon.

Du, S., Tao, Y., \& Martinez, A. M. (2014). Compound facial expressions of emotion. Proceedings of the National Academy of Sciences, 111(15), 1454-1462. https://doi.org/10.1073/ pnas.1322355111

DWDS Digitales Wörterbuch der deutschen Sprache. Retrieved from http://www.dwds.de/ressourcen/korpora/

Edgar, A., \& Sedgwick, P., (Eds). (2007). Cultural Theory: The Key Concepts. London: Routledge.

Garnham, A. (1985). Psycholinguistics: Central Topics. London \& New York: Methuen.

Gawda, B. (2019). The Structure of the Concepts Related to Love Spectrum: Emotional Verbal Fluency Technique Application, Initial Psychometrics, and Its Validation. Journal of Psycholinguistic Research, 48, 1339-1361. https://doi.org./10.1007/s10936-019-09661-y

Izard, C. E. (2011). Forms and functions of emotions: Matters of emotion-cognition interactions. Emotion Review, 3, 371-378. https://doi.org/10.1177/1754073911410737

Kalishchuk, D., \& Lazuka, O. (2015). Osoblyvosti verbalizatsii contseptu freedom v amerykanskomu politychnomu dyskursi dobu "kholodnoyi viyny" [Verbalizing the Concept of Freedom in the Cold War U. S. Political Discourse]. East European Journal of Psycholinguistics, 2(1), 52-58. Retrieved from http://eepl.at.ua/_ld/0/66_eejpl_journal_2.pdf

Kotter-Grühn, D., Scheibe, S., Blanchard-Fields, F. \& Baltes, P. B. (2009). Developmental emergence and functionality of "Sehnsucht" (life longings): The sample case of involuntary 
childlessness in middle-aged women. Psychology and Aging, 24(3), 634-644.

https://doi.org/10.1037/a0016359

Kövecses, Z. 1990. Emotion Concepts. New York: Springer.

Kulpina, V., \& Tatarinov, V. (2018). Dictionary of Linguoculturology Terms as a Solution to the Current Research Problem. Open Journal for Studies in Linguistics, 1(1), 15-20. https://doi.org/10.32591/coas.ojsl.0101.02015k

Kuperman, V., Estes, Z., Brysbaert, M., \& Warriner, A. B. (2014). Emotion and language: Valence and arousal affect word recognition. Journal of Experimental Psychology: General, 143, 1065-1081. https://doi.org/10.1037/a0035669

LCC Leipzig Corpora Collection: Deutsches Nachrichten-Korpus basierend auf Texten gecrawlt 2018. Retrieved from http://corpora.uni-leipzig.de/de/res?word=Sehnsucht\&corpusId= deu_newscrawl-public_2018

Levenson, R. W. (2011). Basic emotion questions. Emotion Review, 3, 379-386. https://doi.org/10.1177/1754073911410743

Ling. (2002). Sistema Elektronnyih Slovarey [System of Electronic Dictionaries]. ABBYY Lingvo 8.0. Software House.

Lomas, T. (2016). Towards a Positive Cross-cultural Lexicography: Enriching Our Emotional Landscape through 216 "Untranslatable" Words Pertaining to Well-being. The Journal of Positive Psychology, 11(5), 546-558. https://doi.org/10.1080/17439760.2015.1127993

Maslova, V. A. (2005). Kognitivnaya lingvistika [Cognitive Linguistics]. Minsk: TetraSistems.

Mayer, S., Scheibe, S. \& Riediger, M. (2008). (Un)Reachable? An empirical differentiation of goals and life longings. European Psychologist, 13(2), 126-140. https://doi.org/10.1027/1016-9040.13.2.126

Mizin, K., Letiucha, L., \& Petrov, O. (2019). Deutsche linguokulturelle Konzepte im Lichte der germanisch-ostslawischen Kontraste: Methode zur Feststellung von spezifischen bzw. einzigartigen Bedeutungen. Germanoslavica, 30(1), 49-70.

Mizin, K., \& Letiucha, L. (2019). The Linguo-Cultural Concept TORSCHLUSSPANIK as the Representative of Ethno-Specific Psycho-Emotional State of Germans. PsycholinguisticsPsiholingvistika, 25(2), 234-249. https://doi.org/10.31470/2309-1797-2019-25-2

NWDTEL. (1993). New Webster's Dictionary and Thesaurus of the English Language. Danbury CT: Lexicon Publications.

Power, M. (2010). Emotion-Focused Cognitive Therapy. Chichester: Wiley.

Scheibe, S., Freund, A. M., \& Baltes, P. B. (2007). Toward a developmental psychology of Sehnsucht (life longings): The optimal (utopian) life. Developmental Psychology, 43(3), 778-795. https://doi.org/10.1037/0012-1649.43.3.778

Scheibe, S., Blanchard-Fields, F., Wiest, M. \& Freund, A. M. (2011). Is longing only for Germans? A cross-cultural comparison of Sehnsucht in Germany and the United States. Developmental Psychology, 47(3), 603-618. https://doi.org/10.1037/a0021807

Spiegel Online. (2004, October 25). “Habseligkeiten” ist schönstes deutsches Wort ["Belongings" is the most beautiful German word]. Retrieved from http://www.spiegel.de/kultur/gesellschaft/0,1518,324670,00.html

Stillings, N. A., Chase, Chr. H., Weisler, S. E., Feinstein, M. H., Garfield, J. L., Rissland, E. L., \& Weisler, S. W. (1995). Cognitive Science: An Introduction. Cambridge, MA: MIT Press. https://doi.org/10.1002/acp.2350030113

Talmy, L. (2007). Foreword. In M. Gonzalez-Marquez, I. Mittelberg, S. Coulson \& M. J. Spivey (Eds.), Methods in Cognitive Linguistics (pp. 11-21). Amsterdam: John Benjamins.

Vater, H. (2006). On the Mental Lexicon. Studi Linguistici e Filologici Online, 4(1), 175-204.

Vorkachev, S. G. (2007). Lyubov' kak lingvokul'turniy kontsept [Love as a Linguocultural Concept]. Moscow: Gnozis [in Russian].

Wierzbicka, A. (1999). Emotions Across Languages and Cultures: Diversity and Universals. Cambridge: Cambridge University Press. https://doi.org/10.1017/CBO9780511521256 
Table 1

\section{Appendix}

The most frequent co-occurrent-like forms and co-occurrents of the word query Sehsucht

\begin{tabular}{|c|c|c|c|}
\hline Co-occurrent-Like Forms & & Co-occurrents & \\
\hline emotions & non-emotions & emotions & non-emotions \\
\hline Basic emotions: & Zuversicht & Liebe 'love; & Heimat 'Motherland' \\
\hline Bedürfnis 'need' & 'confidence; & romance' & Freiheit 'freedom' \\
\hline Neugier 'curiosity' & assurance' & Wunsch 'wish' & Geborgenheit 'security; \\
\hline Wut 'fury, rage; wrath' & Traum & Fernweh & feeling secure, safe' \\
\hline Dankbarkeit 'gratitude' & 'daydream; & 'yearning for & Leben 'life' \\
\hline Melancholie 'melancholy; & dream' & faraway places’ & Frieden 'peace' \\
\hline sadness; longing’ & Fantasie & Heimweh & stillen 'to still' \\
\hline Liebe 'love; romance' & 'fantasy' & 'homesickness' & tief 'deep' \\
\hline Neugierde 'curiosity (often & Überzeugung & Melancholie & Mensch 'human being' \\
\hline to the opposite sex)' & 'conviction & icholy; & Welt 'world' \\
\hline Leidenschaft 'passion' & Motivation & sadness; & wecken 'wake up' \\
\hline Verzweiflung 'despair’ & 'motivation' & longing' & Ferne 'distance' \\
\hline Trauer 'grief; mourning' & Skepsis & Hoffnung 'hope' & voll 'full' \\
\hline Marginal emotions: & 'scepticism, & Schmerz 'pain' & $\begin{array}{l}\text { Ausdruck 'expression; face } \\
\text { expression' }\end{array}$ \\
\hline $\begin{array}{l}\text { Zunelgung affection; } \\
\text { attachment' }\end{array}$ & $\begin{array}{l}\text { unbellet } \\
\text { Erwartung }\end{array}$ & & $\begin{array}{l}\text { expression ' } \\
\text { Einsamkeit 'loneliness' }\end{array}$ \\
\hline Hoffnung 'hope' & 'expectation' & & Gott 'God' \\
\hline Lust 'delight; intimate & Freiheit & & Natur 'nature' \\
\hline pleasure; lust; desire’ & 'freedom' & & wachsen 'to grow' \\
\hline Gier 'appetite, greed' & Heimat & & groß 'great' \\
\hline Angst 'fear' & 'Motherland' & & alt 'old' \\
\hline Vorfreude 'anticipation' & Einsamkeit & & Glück 'happiness' \\
\hline Freude 'joy' & 'loneliness' & & unerfüllt 'unfulfilled' \\
\hline Begeisterung 'enthusiasm; & Verbundenheit & & Wärme 'warmth' \\
\hline rcitement & 'attć & & Entschleunigung 'slowing \\
\hline & & & ne 'sun' \\
\hline & & & Meer 'sea' \\
\hline
\end{tabular}

Table 2

The most frequent left- and right-hand collocates of the word query Sehnsucht

\begin{tabular}{|c|c|c|}
\hline \multicolumn{2}{|c|}{ Right-Hand Collocates } & \\
\hline tief ‘deep’ & & Leben 'life' \\
\hline groß 'great' & & stillen 'to still' \\
\hline voll 'full' & & kennen 'to know' \\
\hline unerfüllt 'unfulfilled' & & treiben 'to cause, drive' \\
\hline unstillbar 'unquenchable' & & wecken 'to wake up' \\
\hline diffus 'vague, blurry’ & & spüren 'to feel' \\
\hline alt 'old' & & packen 'to embrace' \\
\hline menschlich 'human' & & erwarten 'to expect' \\
\hline nostalgisch 'nostalgice' & & erfüllen 'to fill, fulfill' \\
\hline gewiss 'certain' & & singen 'to sing' \\
\hline wachsend 'growing' & & stecken 'to stick in' \\
\hline ungestillt 'unsatisfied' & & darstellen 'to depict; portray' \\
\hline wecken 'wake up’ & & bleiben 'to stay' \\
\hline heimlich 'secret' & & prägen 'to shape; form; remember' \\
\hline spirituell ‘spiritual’ & & \\
\hline unbändig 'unrestrained' & & \\
\hline stark 'strong' & & \\
\hline unendlich 'endless' & & \\
\hline ewiq 'eternal' & & \\
\hline
\end{tabular}

